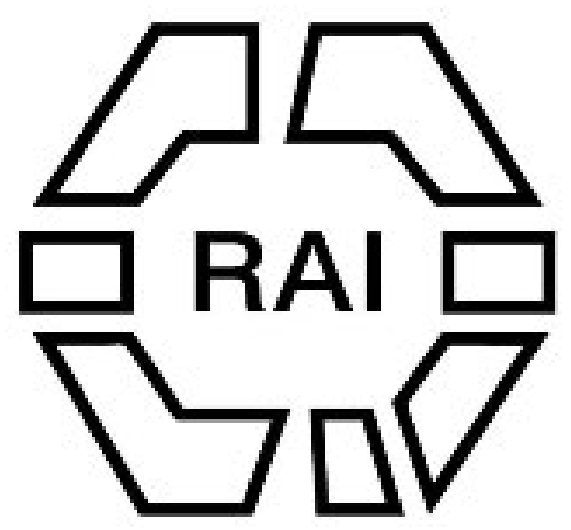

Notes on a Recent Discovery in Finistere

Author(s): Admiral Tremlett

Source: The Tournal of the Anthropological Institute of Great Britain and Ireland, Vol. 19 (1890), pp. 507-508

Published by: Royal Anthropological Institute of Great Britain and Ireland

Stable URL: http://www.jstor.org/stable/2842501

Accessed: 16/06/2014 00:19

Your use of the JSTOR archive indicates your acceptance of the Terms \& Conditions of Use, available at http://www.jstor.org/page/info/about/policies/terms.jsp

JSTOR is a not-for-profit service that helps scholars, researchers, and students discover, use, and build upon a wide range of content in a trusted digital archive. We use information technology and tools to increase productivity and facilitate new forms of scholarship. For more information about JSTOR, please contact support@jstor.org. 
four principal classes; Pultarra, Coomarra, Perula, and Aponoonga. The son of a Perula woman can marry into any division but that of his mother's. In one part of Central Australia, towards the Alice Springs, another curious alteration is made, the son of a "Perula" can only marry an "Apoonunga" woman ; and the offspring of a "Coomarras" only become the hasband of a "Pultarras." The family groups above referred to are perpetuated hereditarily - not in a direct line, but by intermissions. Thus the offspring of a "Pultarra" woman are not "Pultarra," nor "Coomarras," but Perula.

Returning to the Kopperamana tribes (only as regards names of classes), we find all male cousins are called brothers, equally with the children of one father (Ngatata, a Maori, or New Zealand, word by-the-bye) ; and all female cousins, or sisters, indiscriminately under one title-Ngatata. Father, or father's brother, uncle, are called by the same term: Aperi, mother or mother's sister, aunt, is called Andri. To particularise the real parent, the term " andri-waka," or "Aperi-waka, "little mother," or "little father," is sometimes employed.

A man dying and leaving a widow, the native law demands that his brother, however much married before, must take her to wife. She has during her real husband's life already called all his brothers and himself by one term, husband, so she easily falls into the new relationship. In fact, brothers seem to hold their wives in common. Men, however, call their individual wives yungaras, and those to whom they have a secondary claim by right of being brothers-in-law kartetis. No marriage ceremony is performed in South Australian tribes; but the wife is bought of the brothers, the payment often taking place over a course of years, time-payment in wives in fact.

\section{Notes on a recent Discovery in Finistére.}

\section{By Admiral Tremlett.}

Some masons who were employed in splitting erratic blocks of granite for building material, on a common near to the village of Saint Pabu in the Finistére, found near to them a Roman flanged tile. On lifting it they discovered it to be the covering to a cavity in which there had been a wooden box which had been entirely destroyed by decay ; it contained from ten to eleven thousand small copper coins, the greater part of which were plated with silver, and which had been coined at Trèves.

Most of the coins were those of Valerins II, of Diocletian, Constantius Chlorus, Maximilian, Lacinus, Constantine the Great, and VOL. XIX. 
Constantine II, dating from A.D. to the year 360; therefore it was during the fourth century that this treasure was concealed.

As soon as it became known that this treasure had been found all the inhabitants of the neighbourhood commenced to dig in every direction with pickaxe and shovel, but nothing whatever was found excepting, and at a short distance from the former, two silver cups and a patera, or perhaps a cover to the larger cups. No. 1 cup was intact and in a good state of preservation; it weighs 154 grammes. No. 2 has, on the contrary, lost its lower part by oxidisation, the patera has also suffered greatly from the same canse ; it was of thinner silver than the cups. The ornamentation of the cups and also that of the patera was in répoussé. All three, together with all the coins, are now in the possession of $\mathbf{M}$. Du Chatelier, at the Chateau de Kernuz, Pont l'Abbé Lambour, Finistére. A quantity of similar coins have been recently found on a hillock near to the station at Pont L'Abbé.

The supposition seems to be that the Romans were hard pressed, and compelled to quit the district, leaving their money-chest under the granite boulder where it was found; the place is still a common.

Dr. de Closmadenc's late enumeration of the Megaliths in this neighbourhood is as follows :-

\begin{tabular}{|c|c|c|c|c|c|c|}
\hline \multirow{3}{*}{$\begin{array}{l}\text { Menec.. } \\
\text { Petit Menec } \\
\text { Kermario } \\
\text { Manio .. } \\
\text { Kerlescan }\end{array}$} & \multirow{2}{*}{\multicolumn{2}{|c|}{ 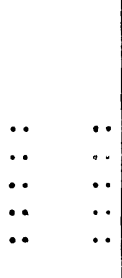 }} & Upright. & Fallen. & $\begin{array}{l}\text { Built up in } \\
\text { walls. }\end{array}$ & Broken. \\
\hline & & & $\begin{array}{r}1,035 \\
187 \\
773 \\
16 \\
251\end{array}$ & $\begin{array}{r}24 \\
1 \\
39 \\
81 \\
11\end{array}$ & $\begin{array}{l}84 \\
80 \\
17 \\
60 \\
31\end{array}$ & $\begin{array}{r}26 \\
5 \\
153 \\
3 \\
13\end{array}$ \\
\hline & & & 2,262 & 156 & 272 & 200 \\
\hline
\end{tabular}

Total menhirs in $1839-2,790$.

Note.-The reason for there being so many broken menhirs now at Kermario is that the State declined to parchase those'beyond the tower of the windmill, in consequence of which the proprietors broke thern up for building material. They also declined to purchase those of the Manio, consequently they will also shortly disappear. 